\title{
MeDicaL JouRial
}

\section{Combined method for simultaneous morphology, immunophenotype and karyotype (MAC) in leukemias}

\author{
Discipline of Hematology and Hemotherapy, Escola Paulista de Medicina-UNIFESP-São Paulo, Brazil
}

In the present study, a combined method (CM) for attaining simultaneous identification of leukemic cell morphology, karyotype and immunophenotype has been evaluated in 21 patients with acute leukemia and 1 with CML in blast crisis were studied for morphology, citochemistry, immunophenotype and karyotype. Karyotype was performed in a bone marrow sample by using conventional techniques. In each case, direct method (DM) and/or three cultures were tried. The CM consisted in separating a small part of the material resulting from any of the cultures or DM, preparing slides through cytospin and immunophenotyping through APAAP method using the same monoclonal antibodies (MoAb) as for diagnosis. In 14 cases, the metaphases proved positive to the MoAb: in 4, the cells with abnormality had their origin defined; in other 4 the karyotype was normal preventing any identification; 6 cases had minimal abnormalities not visible through CM; and in two cases abnormal karyotypes were detected only in the cultures with GM-CSF.

This study showed that $\mathrm{CM}$ is feasible in cases where evident numerical or structural chromosomal abnormalties are present.

UNITERMS: Leukemia, chromosomes, immunophenotype.

\section{INTRODUCTION}

$\mathrm{S}$ everal of the cytogenetic abnormalities in acute leukemias are of clinical importance, once they associate with distinctive modes in which the disease presents itself as well as to prognostic factors. ${ }^{1.2}$

The acquisition of immunophenotyping and cytogenetic data has led to a morphologic, immunophenotypic and chromosomal (MIC) classification 3.4.5 which relates morphological subgroups within $\mathrm{FAB}$ subtypes with specific karyotype abnormalities.

Methods that allow the simultaneous analysis of morphology, immunophenotype and karyotype (MAC) have been described and deserve particular attention. ${ }^{6.7 .8 .9 .10}$

\section{Address for correspondence:}

Maria de Lourdes Lopes Ferrari Chauffaille

Rua Botucatu, $740,3^{\circ}$ andar

São Paulo/SP - Brasil - CEP 04023-006
The idea of concomitantly studying such aspects is of major interest especially in leukemias, as it could possibly indicate the cell lineagers which present chromosomal abnormalities. It may as well indicate the involvement of different cell lineages thus corroborating the heterogeneity of leukemias. ${ }^{10}$ And finally, the combined method makes the analysis of a particular cell possible.

The main differences of the combined method when compared to the conventional technique are: hypotonic treatment (using distilled water instead of $\mathrm{KCl}$ ), which leaves cytoplasm and cell membrane intact, through the utilization of cytospin in the place of air drying smears and the abandon of acid fixatives. ${ }^{10}$

Few studies on the application of this method to leukemic samples have been published up to the present moment, mostly analysing cases where numerical chromosomal abnormalities occurred with results of much consequence. ${ }^{9.10}$ By means of this technique the involvement of multiple lineages (i.e. erythrocytic, myelomonocytic or megakaryocytic) has been 
demonstrated in some cases of acute myeloid leukemia (AML) with monosomy 7. However, not all the cases of AML with trisomy 8 demonstrated such involvement. ${ }^{7}$

We believe that the regular application of this method, though time consuming, would provide invaluable information on leukemic cell origin. Thus, we intended to develop and evaluate the feasibility of this $\mathrm{CM}$ as a regular procedure, using a alkaline phosphatase anti-alkaline phosphatase (APAAP) kit.

\section{MATERIAL AND METHODS}

Twenty-one patients with acute leukemia (18 AML, 2 acute lymphoid leukemia - ALL- and 1 mixed leukemia) and 1 with chronic myeloid leukemia (CML) in blast crisis who were admitted to Hospital S. Paulo have been investigated, or those whose samples (cases 16 and 20) had been sent to us for analysis, from June to December 1992. The average age of these subjects was 32 years (ranging from 2 months to 65 years), being 9 male and 13 female.

The acute leukemia was diagnosed in the presence of blast cells in the patients' peripheral blood or more than $30 \%$ of them in bone marrow. ${ }^{11.12}$ Bone marrow and peripheral blood smears were stained for Leishman, Sudam Black B (SBB), Peroxidase (POX), periodic acid Schiff (PAS), naftol-ASD esterase (ASD), alfa naftil acetate esterase (aES), $\mathrm{NaF}$ and acid phosphatase (Fác) ${ }^{13}$ for morphological and cytochemical diagnosis of the acute leukemia and classified according to FAB. 11.14.15.16

Bone marrow were collected with heparin, separated by Ficoll Hypaque (Pharmacia $\mathrm{AB} /$ Wintrobe) gradient, and then divided for 3 different purposes: for immunophenotyping, cytogenetic and CM.

Immunophenotyping was performed by indirect immunofluorescence, using the following MoAb: $\mathrm{CD}$ 33(My 9), CD 13 (My 7), CD 14 (Leu 9), CD 19 (B4), CD 41 (plt 1), CD 10 (calla), SIg (Coulter) and CD 7 (Dako, Beckton\&Dickson)(Table 1). Positivity was considered when more than $20 \%$ of cells were stained. Bone marrow cells separated by Ficoll-Hypaque gradient were washed 3 times in phosphate buffered solution (PBS), resuspended in RPMI 1640 medium (final concentration $=2 \times 10^{6}$ cells $/$ $\mathrm{ml}$ ) and divided into different tubes with mouse antibody and incubated for 30 minutes at $4^{\circ} \mathrm{C}$. Then fluorescent antimouse antibody was added for $30 \mathrm{~min}$ in a cold camera. The cells were washed in PBS for 2 times, the slides prepared and 100 cells were counted in fluorescent microscope. ${ }^{17}$

For cytogenetic and $\mathrm{CM}$ studies, bone marrow cells were cultivated in a $25 \mathrm{~cm}^{3}$ tissue culture flask with $8 \mathrm{ml}$
RPMI 1640 (Sigma) medium, pH 7.0,20\% fetal calf serum (Cultilab), L-glutamine $2 \mathrm{mM}$ (Sigma) and penicillinstreptomicin (100U; 100ug/ml). Depending on the amount of material obtained (visual observation), 2 or 3 cultures were set up: a short term culture (S), a synchronised culture (MTX), a culture with GM-CSF (GM) and/or a direct method (DM). The cultures were prepared as follows: $\mathrm{S}$ culture: was cultivated for 24 hours at $37^{\circ} \mathrm{C}$; MTX culture: ametopterine (Methotrexate ${ }^{R}$-Lederle) was added 5 hours after set up (final concentration $=10^{-7} \mathrm{M}$ ) for 17 hours at $37^{\circ} \mathrm{C}$ and thymidine (Sigma) was added (final concentration $=10^{-5} \mathrm{M}$ ) for the last 5 hours; GM-culture: GM-CSF (Amgen) $(10 \mathrm{ul} / \mathrm{ml})$ was added for 24 hours; DM: colchicine (Colcemid-Gibco) was immediatly added. ${ }^{18}$ Colchicine $(0,4 \mathrm{ul} / \mathrm{ml})$ was added for the last two hours to all cultures and then the material was spun at $1200 \mathrm{r} / \mathrm{min}$ for $8 \mathrm{~min}$ and the sobrenadant discharged. For the CM 5 , drops (Pasteur pipette) were taken out from the material left from each culture or DM and put in $0.5 \mathrm{ml}$ hypotonic solution (distilled water). The cells were counted in Celm CC 510 eletronic counter and adjusted to a final concentration of 2 to $20 \times 10^{3}$ cells $/ \mathrm{mm}^{3} 50 \mathrm{ul}$ of this solution was put into cytospin cameras and spun at $400 \mathrm{r} /$ $\min$ for $4 \mathrm{~min}$. Meanwhile, cells were being counted (around 5 to 8 minutes) hypotonization was taking place. The slides were fixed in cold formalin-acetone solution for $1 \mathrm{~min}$ at the moment of use and then washed in Tris buffered solution (TBS) $\mathrm{pH} 7.6$ with $2.5 \%$ human $\mathrm{AB}$ serum $(4: 1)$ for $40 \mathrm{~min}$. Then $20 \mathrm{ul}$ of mouse monoclonal antibody (diluted 1:10) was dropped over the cells and incubated for $60 \mathrm{~min}$. After TBS wash rabbit anti-mouse Ig antibody (Dako Z 259) diluted 1:10 in TBS with human AB serum (4:1) for 40 min was added. Another TBS wash and the APAAP complex (Dako D 651) was put over the cells for 40 min diluted 1:50 in TBS. After wash alkalin phophatase substrate was added diluted in TBS with levamisole $1 \mathrm{mM}$ for $20 \mathrm{~min}$. After final wash, the slides were dried and stained for Harris Hematoxilin for $5 \mathrm{~min}$. Blast cells positivity was observed at the microscope as well as positive and negative metaphases. Metaphases that had chromosomal abnormalities were identified. Positive control was done with marrow slides from the same patient. The specimens left over from the cultures or DM were handled for conventional cytogenetic analysis, that is: hypotonization with $\mathrm{KCl} 0.075 \mathrm{M}(10 \mathrm{ml})$ for $20 \mathrm{~min}$, fixation with methanol-acetic acid solution $(1: 3)(10 \mathrm{ml}), 3$ washes in fresh made fixative, and in the next day the slides were made, aged and banded for trypsin G banding. ${ }^{19}$. Cytogenetic abnormalities were described following the International System for Chromosome Nomenclature recommendations. ${ }^{20}$ 


\section{RESULTS:}

Table 1 shows the classification of leukemias, cytochemical reactions and immunophenotype. Case 1 was a M2 AML with characteristic morphology showing Auer rods and pseudo-Chediaki-Higashi anomaly. The karyotype showed loss of $\mathrm{Y}$ chromosome and translocation $\mathrm{t}(8 ; 21)$, an anomaly seen in around $12 \%$ of M2 leukemias. Case 2 was an ALL in relapse with a hyperdiploid karyotype and $\mathrm{G}$ banding was not obtained due to fuzzy chromosomes. Case 3 was a typical M3 with $\mathrm{t}(15 ; 17)$. Cases 4 and 5 were M4 and M2 leukemias respectively, with a very poor banding making it impossible to find

Table 1

Cytochemical reactions, FAB classification and immunophenotype of the leukemias

\begin{tabular}{|c|c|c|c|c|c|c|c|c|c|c|c|c|c|c|c|c|}
\hline CASE & DIAGNOSTIC & POX & SBB & PAS & aES & $\mathrm{NaF}$ & ASD & $\mathrm{AcF}$ & CD33 & $\mathrm{CD} 13$ & CD14 & CD10 & CD19 & CD7 & CD41 & Sig \\
\hline 1 & AML M2 & $99 \%$ & $100 \%$ & $10 \%$ & $95 \%$ & $95 \%$ & $72 \%$ & $52 \%$ & $25 \%$ & $26 \%$ & $13 \%$ & 0 & 0 & 0 & 0 & $2 \%$ \\
\hline 2 & ALL L1r & - & NEG & $10 \%$ & - & - & - & - & 0 & 0 & 0 & $70 \%$ & $78 \%$ & $<1 \%$ & $<1 \%$ & 0 \\
\hline 3 & AML M3 & $100 \%$ & $100 \%$ & DIF & NEG & NEG & - & - & $92 \%$ & $86 \%$ & $1 \%$ & $100 \% d$ & $3 \%$ & $<1 \%$ & $<1 \%$ & 0 \\
\hline 4 & AML M4 & $40 \%$ & $44 \%$ & NEG & $58 \%$ & inhib & - & - & $94 \%$ & $77 \%$ & $64 \%$ & $1 \%$ & $8 \%$ & $10 \%$ & $3 \%$ & $11 \%$ \\
\hline 5 & AML M2r & $60 \%$ & $70 \%$ & DIF & TEC & TEC & - & - & $87 \%$ & $76 \%$ & 0 & 0 & 0 & 0 & 0 & 0 \\
\hline 6 & AML M1 NEG & $96 \%$ & NEG & NEG & NEG & $10 \%$ & NEG & $70 \%$ & $37 \%$ & 0 & 0 & 0 & 0 & 0 & 0 & \\
\hline 7 & AML M2EO & $100 \%$ & $100 \%$ & NEG & - & - & - & - & + & + & 0 & 0 & 0 & 0 & 0 & 0 \\
\hline 8 & AML M1 & $40 \%$ & $90 \%$ & NEG & $30 \%$ & $30 \%$ & - & NEG & $45 \%$ & $44 \%$ & $5 \%$ & 0 & 0 & 0 & $<1 \%$ & 0 \\
\hline 9 & AML M3V & $98 \%$ & $99 \%$ & DIF & DIF & DIF & - & NEG & 0 & $40 \%$ & 0 & 0 & 0 & 0 & 0 & 0 \\
\hline 10 & AML M4L+ & $71 \%$ & $79 \%$ & $10 \%$ & $69 \%$ & inhib & $5 \%$ & - & $61 \%$ & $15 \%$ & $60 \%$ & 0 & $23 \%$ & 0 & 0 & 0 \\
\hline 11 & ALL L1B NEG & NEG & NEG & - & - & - & NEG & 0 & 0 & 0 & $63 \%$ & $25 \%$ & $15 \%$ & 0 & 0 & \\
\hline 12 & AML M3 & $100 \%$ & $100 \%$ & DIF & $85 \%$ & $85 \%$ & - & - & $89 \%$ & $18 \%$ & 0 & 0 & 0 & 0 & 0 & 0 \\
\hline 13 & AML M4 & $5 \%$ & - & $\cdot$ & $51 \%$ & inhib & $9 \%$ & - & $15 \%$ & $48 \%$ & $28 \%$ & $<1 \%$ & $<5 \%$ & $4 \%$ & $1 \%$ & 0 \\
\hline 14 & AML M1 & $90 \%$ & $100 \%$ & NEG & NEG & - & NEG & NEG & $79 \%$ & $41 \%$ & $<1 \%$ & 0 & $<1 \%$ & $45 \%$ & $<2 \%$ & 0 \\
\hline 15 & AML M1 & $98 \%$ & $99 \%$ & $2 \%$ & NEG & NEG & $1 \%$ & - & $77 \%$ & $<5 \%$ & $<5 \%$ & 0 & 0 & $40 \%$ & 0 & $<5 \%$ \\
\hline 16 & Mixed L & NEG & NEG & $39 \%$ & $55 \%$ & inipar & NEG & - & $24 \%$ & $22 \%$ & $<5 \%$ & $37 \%$ & $35 \%$ & $12 \%$ & $<2 \%$ & $11 \%$ \\
\hline 17 & AML M2 & $84 \%$ & $96 \%$ & DIF & NEG & NEG & $50 \%$ & NEG & $21 \%$ & $22 \%$ & $3 \%$ & 0 & $8 \%$ & $1 \%$ & $1 \%$ & 0 \\
\hline 18 & AML M4 & $5 \%$ & $20 \%$ & DIF & $56 \%$ & inhib & - & $\cdot$ & $66 \%$ & $4 \%$ & $16 \%$ & 0 & 0 & 0 & 0 & 0 \\
\hline 19 & AML M1 & $94 \%$ & $100 \%$ & DIF & DIF & DIF & $23 \%$ & - & 0 & 0 & 0 & 0 & 0 & 0 & 0 & 0 \\
\hline 20 & AML M4EO & $63 \%$ & $92 \%$ & NEG & $70 \%$ & inhib & $21 \%$ & - & $26 \%$ & $27 \%$ & $2 \%$ & 0 & 0 & $11 \%$ & 0 & 0 \\
\hline 21 & CML MBC & - & $79 \%$ & NEG & - & $\cdot$ & - & - & $67 \%$ & $31 \%$ & $6 \%$ & 0 & 0 & $11 \%$ & 0 & 0 \\
\hline 22 & AML M2 & $55 \%$ & $40 \%$ & NEG & NEG & NEG & - & - & $41 \%$ & $24 \%$ & $21 \%$ & 0 & 0 & $10 \%$ & 0 & 0 \\
\hline
\end{tabular}

$\mathrm{aES}=$ Alfa naftil acetate esterase

$\mathrm{SBB}=$ Sudam Black $\mathrm{B}$

- = reaction not done

$\mathrm{CD}=$ cluster designation

DIF= difuse positivity

$\mathrm{AcF}=$ acid fosfatase

inhib $=$ reaction inhibited
$A S D=$ naftol $A S D$ acetate esterase

$\mathrm{TEC}=$ technical problem

$0=$ negative result

$\mathrm{MBC}=$ myeloid blast crisis

Eo $=$ eosinophilia

inipar $=$ partial inhibition

$\mathrm{L}+=$ lymphoid component $r=$ relapsed leukemia

Slg= surphace imunoglobuline

$\mathrm{PAS}=$ Periodic Acid Schiff

$M 3 \mathrm{v}=\mathrm{M} 3$ hypogranular variant

$\mathrm{NaF}=$ inhibition by $\mathrm{NaF}$

$\mathrm{POX}=$ peroxidase

$\mathrm{NEG}=$ negative reaction

$\mathrm{M} 4 \mathrm{~L}+=\mathrm{M} 4$ with lymphoid component 
structural abnormalities. Case 6 was a M1 leukemia with a normal karyotype. Case 7 was a M2 AML with $8 \%$ of marrow eosinophils and showed an entirely normal karyotype. Case 8 was a M1 subtype with loss of part of the long arm of chromosome 5. Case 9 was a variant M3 but $\mathrm{t}(15 ; 17)$ was not seen. Case 10 was an infant with leukemia presenting $\mathrm{t}(4 ; 11)$ and classified as monocytic subtype with lymphoid component following HURWTZ\& MIRRO ${ }^{21}$ criteria. Case 11 was a B cell ALL subtype $\mathrm{L} 1$ with loss of a chromosome of group $\mathrm{C}$ and translocation involving long arm of chromosome 1. Case 12 was a M3 with deletion of part of long arm of chromosome 6 and additionaly, in some metaphases monosomy 5. Case 13 was a M4 leukemia with monosomy 7 in a patient with previous exposition to toxic agents. Case 14 was a M1 with material added to the short arm of chromosome 16. Cases 15 and 18 were $\mathrm{M} 1$ and $\mathrm{M} 4$ respectively, with normal karyotypes. Case 16 has been published and was an ALL diagnosed and treated with epipodophyllotoxin some years early and now presenting relapse or a secondary mixed leukemia with $\mathrm{t}(9 ; 22)$ and additionaly, in some metaphases, monosomy $13^{22}$. Case 17 was M2 with hypodiploidia. Case 19, M1 with normal karyotype, though negative showed a immunophenotype presented overt positive peroxidase $(94 \%)$. Case 20 was a typical M4 with eosinophilia and central nervous system infiltration and inversion of chromosome 16. Case 21 was a CML in myeloid blast crisis with only the persistence of Philadelphia chromosome. Case 22 was a M2 in a 53-year-old patient with a complex karyotype with monosomies 2 and 7 , translocations involving $1 \mathrm{q}$ and the presence of a marker chromosome. Some of these patients (cases: $1,3,4,6,12,14,15,17,18$ and 19 ) have been studied correlating survival time and karyotype abnormalities. ${ }^{23}$

Table 2 shows the karyotype and the results of CM. In 14 cases there was some positivity to one or more $\mathrm{MoAb}$ applied on the metaphase. But only in 4 cases $(13,17,21$ and 22) (Fig. 1) could we precisely define to which lineage belonged the cell with cytogenetic abnormality. Among the resting 10 cases, in 4 the karyotype was normal (cases $7,9,15$ and 18) avoiding identifications and in 6, small abnormalities were impossible to be seen through CM (cases $1,8,12,14,16$ and 20). In cases 8 and 12, karyotype abnormality was seen only in GM cultures.

\section{DISCUSSION:}

Among the 22 patients studied, 18 were AML, being M1, M2 and M4 equally frequent. Few cases of ALL in this series is explained by the preponderance of adult patients admitted to our infirmary.

There was $63 \%$ of karyotype abnormalities. In The Fourth International Workshop in Leukemias, ${ }^{24} 50 \%$ of AML presented karyotype abnormalities. In later studies, approximately 70 to $80 \%$ of cases of AML and $50 \%$ of ALL have clonal acquired chromosomal aberration of leukemic cells. ${ }^{1.24 .25 .26 .27}$

MAC method identifies the malignant cell and determines its lineage simultaneously in the intact cells. This has been well demonstraded by other authors ${ }^{7.9 .10}$

Using MAC method with an APAAP kit, we wanted to check its feasibility as a rotinary procedure. We could define the lineage as myeloid in karyotypically abnormal cells only in few cases among 22 consecutevely studied. It became evident that cases with normal karyotype are not suitable for this procedure since there remains as to doubt whether the cytogenetically normal cell belongs to the malignant clone or if it represents the normal residual clone. In cases 15 and 18, wich did not present karyotype abnormalities, we observed that all metaphases in the slides with $\mathrm{CD} 13$ and $\mathrm{CD} 33$ were positive to these myeloid markers. So we could imagine that in these cases normal karyotype was representing malignant clone. Although one can not be certain that cytogenetically normal cells isolated 


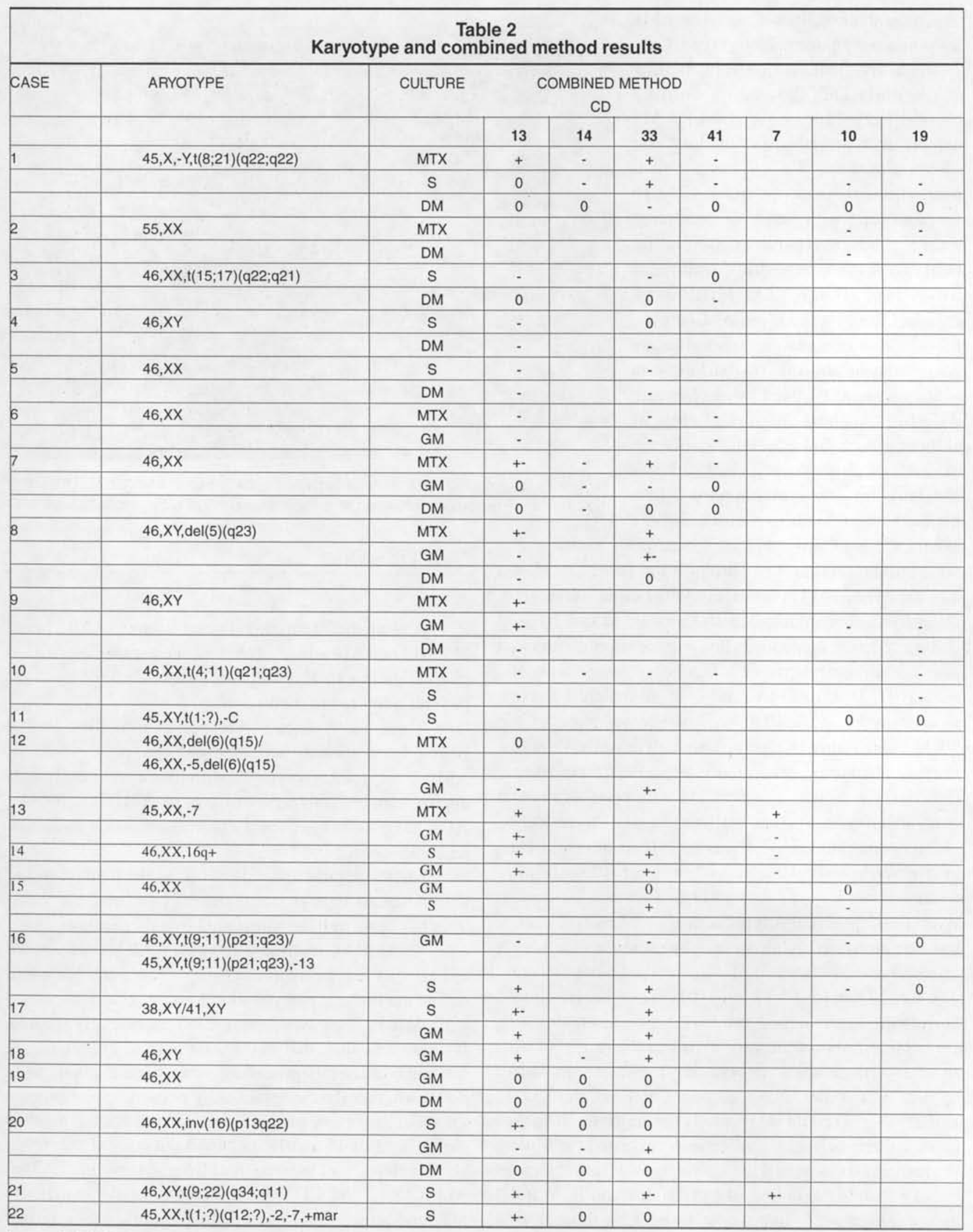

Legend: MTX= culture with ametopterine; $\mathrm{S}=$ short term culture; $\mathrm{GM}=$ culture with GM-CSF; DM=direct method; + positive stain; - negative stain; +- = concomitant presence of positive and negative mitosis; 0 absence of mitosis. 
from tumor samples really reflect the karyotype profile of the tumor.

The simultaneous presence of positive and negative metaphases in MAC method, in 10 cases $(7,8,9,12$, $13,14,17,20,21$ and 22 ) could indicate the proliferation of cells of other lineages.

It became clear that unevident aberrations or diploid karyotype are very difficult to be seen through MAC method, and in these cases probes for fluorescent in situ hybridization (FISH) would help to point out the karyotype abnormality (MACFISH technique).

Some cases, particularly the lymphoid ones, presented very few metaphases to analyse through conventional method as well as through MAC. Perhaps this was due to different reasons such as low mitotic index, small amount of cells aspirated from the patient, small number of metaphases put into cytospin, among other technical problems.

Another interesting point to discuss was the observation that MoAb positivity in MAC method using APAAP was lower when compared to indirect immunofluorescence (IF) done at diagnostic probably due to a different pattern of reaction. ${ }^{28} \mathrm{IF}$ was done immediatly after aspiration or collection of the samples and generally presented positivity, while APAAP took a longer time to be done and could present disappearence of cytoplasmic or surphace antigen recognized by CD 33 (My 9) for instance. ${ }^{28}$ Besides that, the cells stained for APAAP had been cultivated or submitted to DM, or in other words, had gone through handling that could explain the altered bindings to MoAb. Yet these cells had gone through hypotonia and swelling and thus had suffered modifications that could alter surphace antigens.

In 2 cases ( 8 and 12), karyotype abnormalities were found only in GM culture. It has already been shown that GM-CSF may induce proliferation of abnormal clonogenic cells in human myeloid diseases such as AML and myelodysplastic syndromes. ${ }^{26}$ Leukemic cells from bone marrow have an increased response to GM-CSF in a pattern called "leukemic specific", where there are stimulation of cytogenetically abnormal cells, proliferative advantage to malignant cells in a mixed population (normal-abnormal) and a possible influence in the karyotype.$^{27.29 .30}$ This could mean that GM induced the proliferation of malignant clonal cells, and this aspect should be better studied in future works.

This study showed that the combined method is feasible in cases with numerical or evident structural chromosomal abnormalities, and not as a routine procedure. Associated with probes for FISH, it will bring much more interesting details.

\section{RESUMO}

Este trabalho avaliou um método combinado $(\mathrm{MC})$ para identificação simultânea da morfologia, cariótipo e imunofenótipo da célula leucèmica. Foram estudados 21 pacientes com leucemia aguda e $1 \mathrm{com} \mathrm{LMC} \mathrm{em} \mathrm{crise} \mathrm{blástica} \mathrm{através} \mathrm{da} \mathrm{morfologia,}$ citoquímica, imunofenotipagem e citogenética. O cariótipo foi feito em material proveniente da medula óssea pelas técnicas convencionais e para cada caso, foi feito o método direto (MD) e/ou três culturas. O MC consistia em separar pequena parte do material de qualquer cultura ou MD, preparar as lâminas através de citocentrifuga e fazer a imunofenotipagem pelo método do APAAP com os mesmos anticorpos monoclonais (AcMo) usados ao diagnóstico. Em 14 casos as metáfases mostraram positividade para os AcMo: em 4 as células com anormalidades tiveram sua origem definida, em 4 casos o cariótipo era normal impedindo identificações e 6 tinham aberraçōes minimas impossiveis de serem vistas através do MC. Em dois casos o cariótipo anormal foi encontrado apenas nas culturas com GM-CSF. O estudo mostrou que o MC é válido para casos com alteraçōes cromossômicas numéricas ou estruturais evidentes.

\section{REFERENCES:}

1. Mufti GJ, Flandrin G, Sandberg AA, Kanfer EJ. An Atlas of malignant hematology, cytology, histology and cytogenetics. Marin Dunitz editor 1996:1-134.

2. Marosi C, Koller U, Koller-Weber E et al. Prognostic impact of karyotype and immunologic phenotype in 125 adult patients with de novo AML. Cancer Genet Cytogenet 1992; 61: 14-25.

3. First International Workshop in MIC ClassificationMorphologic, Immunologic and Cytogenentics Working Classification of Acute Lymphoblastic Leukemias Cancer Genet Cytogenet 1986; 23:189-97.

4. Second International Workshop in MIC classification on the acute myeloid leukemia. Br J Haematol 1988: 68:487-94. 
5. Third MIC Cooperative Group. Recomendations for the morphologic, immunologic and cytogenetic (MIC) working classification of the primary therapy related myelodysplastic disorders. Cancer Genet Cytogenet 1988; 32:1-10.

6. Knuutila, S, Keinänen M. Chromosome banding techniques for mophologically classifies cell. Cytogenet Cell Genet 1985;39: 70-2.

7. Keinänen M, Griffin J, Bloomfield CD, Machincki, de la Chapelle A. Clonal chromosomal abnormalities showing multiple cell lineage involvement in acute myeloid leukemia. N Engl J Med 1988;318:1153-8.

8. Autio K, Elonen E, Teerenhovi L, Knuutila S. Cytogenetic and immunologic characterization of mitotic cells in CLL. Eur J Haematol 1987;39:289-98.

9. Nölle I, Schlegelberger B, Schimitz N, Bödewadt-Radzun $\mathrm{S}$, Grote W. Acute monocytic leukemia with translocation $t(1 ; 11)(p 31 ; q 23)$ : Simultaneous staining of chromosomes and cell surface antigens. Haematol Blut Transf 1990;33:145-9.

10. Knuutila S, Teerenhovi L. Immunophenotyping of aneuploid cells. Cancer Genet Cytogenet 1989;41: 1-17.

11. Bennet JM, Catovsky D, Daniel MT, Flandrin G, Galton DAG, Gralnick HR, Sultan C. Proposals for the classification of myelodysplastic syndromes. Br J Haematol 1982; 51: 189-99.

12. Hirsch-Ginsberg C, Huh YO, Kagan J, Liang JC, Stass S. Advances in the diagnosis of acute leukemia. Hematol Oncol Clinic of N America 1993;7:1-46,1993.

13. Dacie JV, Lewis SM. Blood cell cytochemistry and supplementary techniques In Practical Hematology 6th, Edinbourgh Churchill Livingstone, 1984:84-99.

14. Bennet JM, Catovsky D, Daniel MT, Flandrin,G, Galton DAG, Gralnick HR, Sultan C. Proposals for the classification of the acute leukemias: French-American- British(FAB) cooperative group. Br J Haematol1976; 33: 451-8.

15. Bennet, JM, Catovsky D, Daniel MT, Flandrin G, Galton DAG, Gralnick HR, Sultan C. Criteria for the diagnosis of acute leukemia of megakaryocyte lineage (M7). Ann Inter Med 1985;103:460-2.

16. Bennet JM, Catovsky D, Daniel MT, Flandrin G, Galton DAG, Gralnick HR, Sultan C. Proposal for the recognition of minimally differentiated acute myeloid leukemia (AMLM0). British J of Haematol 1991;78:325-9.
17. Kurec AS, Davey FR. Lymphocyte markers in Willimas W, Beutler E, Erslev AJ, Lichtman MA: Hematology 4th ,N York McGraw Hill, 1990:1756-58.

18. Coutinho V, Bottura C. Método direto para o estudo de cromossomos humanos. Rev. Paul Med 1969;72:5-13.

19. Seabright MA. A rapid banding technique for human chromosomes. Lancet 1971;2:971-2.

20. ISCN- Guidelines for Cancer Cytogenetics, Supplement to An International System for human cytogenetic nomenclature.1991 Mitelman, F.(ed) Karger, S., Basel,

21. Hurwitz CA, Mirro JRJ. Mixed lineage leukemia and assynchronous antigen expression. Hematol Oncol Clinics N Am 1990; 4:767-94.

22. Chauffaille MLLF, Yamamoto M, Odone F et al. A t $(9 ; 11)$ translocation in childhood acute mixed leukemia. São Paulo Medical Journ 1996;114(2): 1127-30.

23. Chauffaille MLLF, Yamamoto M, Moncau JEC, Braga GW, SoutoEX, Kerbauy J. Alterações Citogenéticas como fatores Prognósticos em LMA. Rev da AMB 1996; in press.

24. Fourth International Workshop of Chromosomes in Leukemia. A prognostic study of acute non lymphocytic leukemia. Cancer Genet Cytogenetc 1984;11:249-360.

25. Heim S, Mitelman F. Acute Meyloid Leukemia IN Cancer Cytogenetics 2nd Ed Wiley Liss, N York, 1995 pp69-140.

26. Demetri GD, Antman KHS. Granulocyte-Macrophage colony-stimulating factor (GM-CSF) preclinical and clinical investigation. Sem in Oncol 1992;19(4):362-385.

27. Minamihisamatsu M, Okada T, Jinnali I, Ishiara T. A culture technique for chromosome analysis in human myeioid leukemias. Cancer Genet Cytogenet 1986,19:345-50.

28. Sacchi S, Marietta M, Vecchi A, Morselli S, Longo R, Grande A, Torelli U. The use of the alkaline phosphatase-antialkaline phosphatase technique for immunophenotyping acute myeloid leukemia. Acta Haematol 1991;85:6-11.

29. Haase D, Fonatsch C. Monosomy 7 provides a proliferative advantage for leukemic cells under incubation with GM-CSF in vitro. Blut 1990;61:322-23.

30. Haase D, Fonatsch C. Karyotype in vitro response to GMCSF analysis of bonemarrow cultures in leukemia, myelodysplastic and aplastic anemia. Blut 1990;60:192-7. 